\title{
Hydro-catalytic isomerization of light gasoline fraction of Zhanazhol field's oil
}

\author{
Amanzhan Saginayev ${ }^{1}$, Lyazzat Tastanova ${ }^{2}$, Ainagul Apendina ${ }^{2}$, Nyasima Ishmukhanbetova $^{1}$, and Elena Dosmurzina ${ }^{2}$ \\ ${ }^{1}$ NP JSC "S. Utebaev Atyrau of Oil and Gas University", Kazakhstan \\ ${ }^{2}$ NP JSC “K. Zhubanov Aktobe Regional University”, Kazakhstan
}

\begin{abstract}
The purpose of the present work is to show that light straight-run gasoline fraction can be used as feedstock for hydro-catalytic isomerization process, and the isomerized product can serve as a component for obtaining pure ecological commercial gasoline brand Euro-4 and Euro-5. Transformation of n-alkanes of Zhanazhol oil's light gasoline fraction with boiling temperature $180^{\circ} \mathrm{C}$ was studied. Isomerization was carried out in a flow unit with a stationary layer of modified sample of industrial aluminum-platinum catalyst at $200-300^{\circ} \mathrm{C}$ and $2.0-4.0 \mathrm{MPa}$, with volume feed rate of 1.0-3.0 h-1 and circulation ratio of hydrogen containing gas circulation $1000-1500 \mathrm{~m}^{3} / \mathrm{m}^{3}$ of catalyst feed. Light gasoline fraction are subjected to a number of chemical transformations: n-paraffins isomerization, five-membered and six-membered cycloalkanes dehydroisomerization and hydrocracking. n-Alkanes are isomerized in iso-alkanes, naphthenic hydrocarbons are first subjected to hydrocracking with opening the cycle and forming $n$-alkanes, which are then isomerized into iso-alkanes. Thus, the reaction products contain isopentane, 2,3-dimethylbutane with octane number 92 and 104 correspondingly, and other iso-paraffinic hydrocarbons that lead to raise of gasoline octane number. By study of individual hydrocarbon composition of feedstock and isomerizate it is possible to establish some regularities hydrocarbons in the process of hydro-catalytic isomerization of light gasoline fraction.
\end{abstract}

\section{Introduction}

Development of rational methods for processing various oils and gas condensates from new, rich fields of the Republic of Kazakhstan can effectively solve the problem of meeting the country's need for high quality motor and boiler fuels, lubricants, petroleum coke and feedstock foe petrochemistry.

Isomerization is the process of low-octane oil fractions processing in order to obtain high-octane components of commercial gasoline. Isomerizate obtained in this process is mixed with reformate (gasoline fraction of reforming process) in proportions required by technical norms. Typically, $30-40 \%$ of isomerizate is added to reformate. When isomerizate is mixed with reformate at a ratio of $33 \%$ to $67 \%$ by weight, the output is gasoline with octane number 87.4. Il the octane number of components is lower than this value, it is necessary to raise the proportion of isomerizate in mixture. The higher is the proportion of isomerizate, the higher is the quality of the resulting fuel. The blending process not only increases the octane number, but also has positive effect on compliance with environmental requirements for gasoline composition.

Total capacity of isomerization process in world oil refining is steadily increasing and now is more than 50 million tons per year (by isomerizate). About of the total number of plants operated in the world are located in the
USA and $30 \%$ - in Europe. At present 30 isomerization units with different technological schemes and capacities are under construction.

Process of isomerization of gasoline fractions C5-C6 is characterized by essential advantages including high yield (96-99\%) and significant increase of product octane number (up to 92-93 points according to research method), relatively low cost of isomerizate compared to other non-aromatic components with high octane number. Isomerizates are ideal components of gasoline blending which practically do not contain sulfur, olefins and aromatics, have little difference between the octane numbers according to the research method and the motor method and in addition increase the octane number of gasoline light fraction boiling up to $100{ }^{\circ} \mathrm{C}$.

The above-mentioned advantages determine the priority importance of isomerization and its economic feasibility in solving the problem of improving quality and environmental purity of modern automotive gasoline.

\section{Literature review}

Process of light gasoline fractions isomerization has become one of the demanded processes of oil refining due to objective advantages of isomerizate as high-octane component of ecologically clean gasoline. One of the promising ways to improve the performance of gasoline 
fractions is the process of catalytic isomerization of normal paraffin hydrocarbons (n-hexane) over zeolites with high content of silica [1-5]. Isomerization of $n$ alkanes produces isoalkanes, which have higher octane numbers (ON) [6-10].

The attractiveness of isomerization process is connected with environmental protection issue. More and more strict requirements are imposed on motor gasolines: total absence of lead; reduction of benzene, sulfur, unsaturated hydrocarbons, aromatic compounds content; limitation of oxygen-containing compounds content; reduction of saturated vapor pressure; control of fractional composition. These trends have a significant impact on the ways of obtaining automotive fuels. When considering environmental characteristics of typical gasoline production processes, it is obvious that isomerizate is the most desirable component of commercial gasoline in addition to alkylates and oxygencontaining additives.

Gasoline with high octane number, meeting the environmental requirements, is carried out by addition of high-octane isomerizates of pentane-hexane fractions and iso-octanes. This significantly reduces the content of benzene and other aromatic hydrocarbons in commercial gasoline, which are ecologically cleaner components of commercial grade high-octane automotive gasoline. [11, $12]$.

In recent years much attention is paid to development of catalysts for $\mathrm{C}_{5}-\mathrm{C}_{7} n$-alkanes hydro isomerization into branched hydrocarbons. Different types of catalysts can be used for $n$-alkanes isomerization processes: FriedelCrafts catalysts, chlorinated aluminum oxide, zeolites, sulfated and tungsten containing zirconium dioxide, heteropolyacids. At present platinum containing catalysts based on chlorinated aluminum oxide, zeolites and sulfated zirconium dioxide are used in industry for isomerization of pentane-hexane fraction. Due to their high performance, characteristics $\mathrm{SO}_{4} / \mathrm{ZrO}_{2}$ based catalysts can be considered as the most promising.

It is known, that bifunctional platinum catalysts in which transition metal is fixed on metal oxide show higher activity in $n$-hexane isomerization [13-15].

In order to select more active and selective catalyst we have studied the influence of technological parameters on conversion of $\mathrm{C}_{5}-\mathrm{C}_{7} n$-alkanes contained in light gasoline fraction (start of boiling at $62{ }^{\circ} \mathrm{C}$ ) of Zhanazhol oil.

\section{Materials and methods}

Study of gasoline fraction $n$-alkanes conversion was carried out in high pressure flow unit with stationary layer of catalyst. The process was carried out on modified sample of industrial aluminum-platinum catalyst of isomerization at 200-300 ${ }^{\circ} \mathrm{C}$ and 2.0-4.0 $\mathrm{MPa}$, with volume feed rate of $1.0-3.0 \mathrm{~h}^{-1}$ and volume ratio of hydrogen containing gas circulation $1000-1500 \mathrm{~m}^{3} / \mathrm{m}^{3}$ of feed. Optimal process parameters were determined as a result of study: temperature $250{ }^{\circ} \mathrm{C}$, pressure $3.0 \mathrm{MPa}$, volume feed rate $2.0 \mathrm{~h}^{-1}$.

\section{Results and discussion}

Comparative study of physical-chemical properties detailed and individual hydrocarbon composition of initial gasoline and isomerizate obtained in hydro catalytic isomerization is of great importance for clarification of chemistry and mechanism of studied process.

Physicochemical properties and group hydrocarbon composition of feedstock (hydrogenate) and isomerizate obtained in laboratory unit at optimal process conditions $\left(\mathrm{T}=250{ }^{\circ} \mathrm{C}, \mathrm{P}=2.0 \mathrm{MPa}\right.$, optimal volume feed rate 2.0 $\left.\mathrm{h}^{-1}\right)$ are shown in Table 1 .

Table 1. Physicochemical properties of feedstock and isomerizate.

\begin{tabular}{|l|c|c|}
\hline Characteristics & Hydrogenate & Isomerizate \\
\hline Density at $20^{\circ} \mathrm{C}, \mathrm{g} / \mathrm{cm}^{3}$ & 0.6485 & 0.6840 \\
\hline $\begin{array}{l}\text { Fractional composition at } \\
\text { the following temperature }\end{array}$ & & \\
parameters, ${ }^{\circ} \mathrm{C}$ & 1.0 & 1.0 \\
$\quad$ Start of boiling & 34.1 & 20.5 \\
$10 \%$ boil off at & 37.5 & 32.6 \\
$50 \%$ boil off at & 69.9 & 58.8 \\
$90 \%$ boil off at & 74.1 & 62.5 \\
$95 \%$ boil off at & 98.4 & 68.0 \\
End of boiling & & \\
\hline Total sulfur content, \% wt. & 0.0005 & not \\
\hline Octane number: & 71.3 & 92.8 \\
The motor method & 70.7 & 94.2 \\
$\quad$ The research method & & \\
\hline Saturated vapor pressure, & 2191.0 & - \\
mm Hg & 44.7 & - \\
\hline Lower calorific value, $\mathrm{J} / \mathrm{kg}$ & 48.3 & - \\
\hline Higher calorific value, $\mathrm{J} / \mathrm{kg}$ & & \\
\hline Hydrocarbon group & & \\
composition, \% wt. & 25.94 & 5.56 \\
$n$-paraffins & 32.25 & 66.41 \\
isoparaffins & 20.18 & 18.70 \\
naphthenes & 6.22 & 5.42 \\
aromatics & 15.40 & 3.81 \\
\hline unidentified & & \\
\hline
\end{tabular}

In the reactor $n$-paraffins and naphthenes undergo reactions of isomerization and hydro cracking forming isoparaffins and light hydrocarbons. Content of isoparaffins after hydro catalytic isomerization increases more than twice.

There is a complex of active centers, each of which is responsible for a particular direction of the process, on acting surface of the polyfunctional catalyst. For example, activation of molecular hydrogen takes place at Lewis (L) and Bronsted (B) acid centers [16]. Modified with metals Bronsted centers take part in isomerization and hydrogenation reactions while metal containing Lewis centers are active in reactions of hydrogenation $\left(\mathrm{M}^{\circ}-\mathrm{L}\right)$ and $\mathrm{C}-\mathrm{SH}$ bond breaking [17].

The composition of isomerization products indicates that $\mathrm{C}-\mathrm{C}$ bond breaking reaction, i.e., hydrocracking proceeds along with hydrogen atom detachment. Two active intermediate complexes $\mathrm{CH}_{3} \bullet$ catalyst and $\mathrm{C}_{6} \mathrm{H}_{13} \cdot$ catalyst adsorbed on Bronsted acid centers are formed as a result of hydrocracking [13]. These active 
intermediate complexes further take part in the stages where hydro-isomerization and hydrogenation reactions take place. Intermediate complex $\mathrm{C}_{6} \mathrm{H}_{13}$ catalyst can interact with neighboring active centers undergoing isomerization and hydrogenation. The proposed stages of $n$-heptane transformation are confirmed by composition of products, which contain methane, ethane, propane, butane, isobutane, pentane, isopentane, hexane and isohexane.

During isomerization of gasoline fraction hydrocarbon feedstock undergoes a number of chemical processes: isomerization of $n$-paraffins, dehydroisomerization of five-membered cycloalkanes and hydrocracking $[9,14,16,17]$. Basic reactions take place in reactor in series and in parallel, leading to increase in concentration of isoparaffin hydrocarbons, which contribute to increase of gasoline octane number. Reactions of $n$-paraffin hydrocarbons isomerization are important for increasing octane number, in particular $n$ pentane isomerization produces isopentane, and 2,3dimethyl butane is produced from $\mathrm{n}$-hexane:

$$
\begin{array}{cc}
\mathrm{CH}_{3} \mathrm{CH}_{2} \mathrm{CH}_{2} \mathrm{CH}_{2} \mathrm{CH}_{3} & \leftrightarrows \mathrm{CH}_{3} \mathrm{CH}\left(\mathrm{CH}_{3}\right) \mathrm{CH}_{2} \mathrm{CH}_{3} \\
(\mathrm{ON}=62) & (\mathrm{ON}=92) \\
\mathrm{CH}_{3} \mathrm{CH}_{2} \mathrm{CH}_{2} \mathrm{CH}_{2} \mathrm{CH}_{2} \mathrm{CH}_{3} \leftrightarrows \mathrm{CH}_{3} \mathrm{CH}\left(\mathrm{CH}_{3}\right) \mathrm{CH}\left(\mathrm{CH}_{3}\right) \mathrm{CH}_{3} \\
(\mathrm{ON}=30) & (\mathrm{ON}=104)
\end{array}
$$

Isomerization reactions are reversible and the final distribution of isomers is based on equilibrium composition that depends on reaction conditions and kinetics.

In addition to isomerization reactions, other side reactions occur, some of them are undesirable. Dehydroisomerization of five-membered cycloalkanes opens naphthenic rings, for example, hexane is formed from methyl cyclopentane:

$$
\mathrm{C}_{5} \mathrm{H}_{11} \mathrm{CH}_{3} \rightarrow \mathrm{C}_{6} \mathrm{H}_{14}
$$

The naphthenes contained in the feedstock include cyclopentane, methyl cyclopentane and cyclohexane. These naphthenic rings are broken and hydrogenated forming paraffins. The fraction of ring-breaking reactions increases with temperature, their occurrence is determined by equilibrium compositions for specific reactor operating conditions. Under typical isomerization reactor conditions, conversion of naphthenic rings to paraffins is about $10-20 \%$.

Naphthenic or other cyclic components tend to inhibit isomerization reactions and hence their presence in large quantities is undesirable. Cyclic components of feedstock are absorbed on catalyst reducing the number of active centers available for paraffins isomerization [9, $14,17]$. They also consume hydrogen, which leads to release of heat that is undesirable from the point of view of isomerization reaction equilibrium. Despite the undesirability of these compounds, they are natural constituent of $\mathrm{C}_{5} / \mathrm{C}_{6}$ fraction. It is difficult to remove them without also removing other desired components of feedstock.
Individual hydrocarbon composition of feedstock (hydrogenate) and products (isomerizate) was determined on «Saturn - 2100» Varian chromatographymass-spectrometer. Stationary phase was HayeSepR 80100 Mech, carrier gas - helium, temperature regime - 10-

\begin{tabular}{|c|c|c|}
\hline \multirow{2}{*}{ Hydrocarbons } & \multicolumn{2}{|c|}{ Hydrocarbons share, $\%$} \\
\hline & Feedstock & Product \\
\hline $\mathrm{C}_{1}+\mathrm{C}_{2}+\mathrm{C}_{3}$ not identified & 0.01 & 0.01 \\
\hline Isobutane & 0.05 & 0.86 \\
\hline n-Butane & 0.29 & 0.12 \\
\hline 2,2-Dimethylpropane & 0.01 & 0.02 \\
\hline 2-Methylbutane & 1.80 & 2.86 \\
\hline$n$-Pentane & 3.90 & 0.50 \\
\hline 2,2-Dimethylbutane & 0.22 & 1.96 \\
\hline Cyclopentane & 0.49 & 0.01 \\
\hline 2,3-Dimethylbutane & 0.21 & 2.48 \\
\hline 2- Methylpentane & 5.06 & 6.50 \\
\hline 3- Methylbutane & 3.57 & 6.00 \\
\hline$n$-Hexane & 8.17 & 0.82 \\
\hline Methylcyclopentane & 3.24 & 1.24 \\
\hline 2,4-Dimethylpentane & 0.41 & 2.42 \\
\hline 2,2,3-Trimethylbutane & 0.09 & 2.16 \\
\hline 3,3-Dimethylpentane & 1.17 & 3.12 \\
\hline Cyclohexane & 3.15 & 2.12 \\
\hline Benzene & 3.40 & 3.06 \\
\hline 3-Methylhexane & 3.02 & 5.40 \\
\hline cis-1,3-Dimethylcyclopentane & 1.25 & 2.01 \\
\hline $\begin{array}{l}\text { trans-1,3-Dimethylcyclopentane }+3 \text { - } \\
\text { ethylpentane }\end{array}$ & 1.10 & 3.02 \\
\hline $\begin{array}{l}\text { trans-1,2-Dimethyl cyclopentane }+ \\
\text { 2,2,4-trimethylpentane }\end{array}$ & 2.20 & 3.40 \\
\hline$n$-Heptane & 7.07 & 2.68 \\
\hline Methylcyclohexane & 6.24 & 3.12 \\
\hline 2.2-Dimethylhexane & 0.96 & 1.88 \\
\hline $\begin{array}{l}\text { Ethylcyclopentane }+2,5- \\
\text { dimethylhexane }\end{array}$ & 0.90 & 1.20 \\
\hline 2,4-Dimethylhexane & 0.49 & 3.10 \\
\hline cis, trans-1,2,4-Trimethylcyclo-pentane & 2.30 & 4.15 \\
\hline Toluene & 2.82 & 2.36 \\
\hline 2.3-Dimethylhexane & 1.07 & 3.18 \\
\hline 4-Methylheptane & 4.38 & 7.80 \\
\hline 2,3,4-Trimethylpentane & 5.48 & 8.12 \\
\hline 1.1-Dimethylcyclohexane & 0.49 & 1.20 \\
\hline cis-3,3-Ethylmethylcyclopentane & 0.34 & 1.04 \\
\hline 3-Methyl-3-ethylpentane & 1.00 & 5.16 \\
\hline 3-Methyl heptane & 1.16 & 1.80 \\
\hline$n$-Octane & 6.51 & 1.44 \\
\hline $\mathrm{C}_{9}$ not identified & 7.03 & 1.05 \\
\hline $\mathrm{C}_{10}$ not identified & 6.91 & 0.54 \\
\hline $\mathrm{C}_{11}$ not identified & 0.89 & 0.02 \\
\hline $\mathrm{C}_{12}$ not identified & 0.02 & - \\
\hline $\mathrm{C}_{13}$ not identified & 0.01 & - \\
\hline $\mathrm{C}_{14}$ not identified & 0.01 & - \\
\hline $\mathrm{C}_{15}$ not identified & 0.15 & - \\
\hline $\mathrm{C}_{16}$ not identified & 0.16 & - \\
\hline $\mathrm{C}_{17}$ not identified & 0.01 & - \\
\hline $\mathrm{C}_{18}$ not identified & 0.01 & - \\
\hline $\mathrm{C}_{19}$ not identified & 0.02 & - \\
\hline $\mathrm{C}_{20}$ not identified & 0.02 & - \\
\hline $\mathrm{C}_{21}$ not identified & 0.01 & - \\
\hline $\mathrm{C}_{22}$ not identified & 0.01 & - \\
\hline $\mathrm{C}_{23}$ not identified & 0.01 & - \\
\hline $\mathrm{C}_{24}$ not identified & 0.01 & - \\
\hline $\mathrm{C}_{25}$ not identified & 0.01 & - \\
\hline $\mathrm{C}_{26}$ not identified & 0.01 & - \\
\hline
\end{tabular}
$420^{\circ} \mathrm{C}$.

The yield time and percentage of hydrocarbons in the feed and product are shown in Table 2.

Table 2. Hydrocarbons yield order and percentage in feedstock and in product. 
Along with the listed reactions leading to accumulation of isoparaffins in isomerizate, other processes, such as alkanes hydrocracking followed by hydrogenation of fragments and isomerization of formed light alkanes also occur.

The proportion of hydrocracking reactions of $\mathrm{C}_{5}-\mathrm{C}_{6}$ compounds is small. Nevertheless, $\mathrm{C}_{7}$ paraffins are easily hydrocracked to form $\mathrm{C}_{3}$ and $\mathrm{C}_{4}$ components. Hydrocracking reactions consume hydrogen, so the content of $\mathrm{C}_{7}$ compounds in isomerization process feedstock is limited.

\section{Conclusions}

It is shown that study of individual hydrocarbon composition of feedstock and isomerizate allows to establish some regularities of chemical transformation of individual hydrocarbons which take place in the process of light gasoline fraction isomerization.

It has been established that paraffins isomerization leads to intensive formation of isoparaffin hydrocarbons in isomerizate, which increases the octane number of gasoline.

It has been revealed that in catalytic isomerization process in the reactor there is also hydrocracking of paraffin hydrocarbons, during which smaller molecular weight hydrocarbons are formed from large molecules with their subsequent hydrogenation.

The work was supported by the program-targeted funding "Science Fund" of the Ministry of Education and Science of the Republic of Kazakhstan № BRO5236302.

\section{References}

1. Loc Luu Cam, Tri Nguyen, Thoa Dao Thi Kim, N.A. Gaidai, Yu.A. Agafonov, Anh Ha Cam, Cuong Hoang Tien, A.L. Lapidus. Kinet. Catal. 58, 311320(2017).

2. A.F. Gizetdinova, T.P. Kiseleva, O.M. Posokhova, I.D. Reznichenko, M.Yu. Yuriev, S.A. Skornikova. Kataliz v promyshlennosti. 5, 38-43(2014). (in Russ.)

3. H. Li, Ch. Liu, Yan Wang, J. Zheng. Royal Soc. Chem. 8, 28909-28917(2018).

4. A.Z. Mamedova, S.E. Mirzalieva, E.I. Ahmedov, N.F. Ahmedova, S.E. Mamedov. Bul. Baku Univer. 4, 5-20 (2014). (in Russ.)

5. G. Gatti, D. Olivera, V. Sacchetto, M. Cossi, L. Brachi, L. Marchese, Ch. Bisio Chemphyschem, 18, 2374-2380 (2017).

6. A.N. Shakun, M.L. Fedorova. Kataliz v promyshlensti. 5, 29-37(2014). (In Russ.)

7. Miao Zhang, Chuang Li, Yujing Chen, Chi-Wing Tsang, Qiumin Zhang, Changhai Liang. Catal. Sci. Technol. 6, 8016-8023(2016).

8. Miao Zhang, Lei Wang, Yujing Chen, Qiumin Zhang, Changhai Liang. J Energy Chem, 25, 539544 (2016).
9. P. Snehalkumar, K. Pant, J. Mathew, K. Kishore, S.M. Pai, B.L. Newalkar. Energy Fuels, 29, 1066 1075 (2015).

10. A. Aitani, M.N. Akhtar, S. Al-Khattaf, Y. Jin, O. Koseoglo, M.T. Klein. Energy Fuels, 33, 3828-3843 (2019).

11. S.K. Jesudoss, J.J. Vijaya, P.I. Rajan, L.J. Kennedy, M. Mkandawire. Materials Research Express. 6, 125032-125040(2019).

12. E.V. Chuparev Zhurnal prikladnoy khimii, 87, 760766(2014). (in Russ.)

13. M.D. Smolikov, L.I. Bikmetova, K.V. Kazantsev, E.V. Zatolokina, A.S. Belyi. Kataliz v promyshlennosti, 18, 45-49(2018). (in Russ.)

14. M. Cai, A. Palcic, V. Subramanian, S. Moldovan, O. Ersen, V. Valtchev, V.V. Ordomsky, A.Y. Khodakov. J. Catal., 338. 227-238(2016).

15. K.V. Kazantsev, L.I. Bikmetova, O.V. Dzhikiya, M.D. Smolikov, A.S. Belyi. Proc. Engineer., 152, 34-39(2016).

16. V.A. Shkurenok, M.D. Smolikov, S.S. Yablokova, D.I. Kiryanov, A.S. Belyi, E.A. Paukshtis, N.N. Leonteva, T.I. Gulyaeva, A.V. Shilova, V.A. Drozdov. Proc. Engineer. 113, 62-67(2015).

17. M.D. Smolikov, V.B. Goncharov, E.M. Sadovskaya, K.V. Kazantsev, E.V. Zatolokina, D.I. Kir'yanov, E.A. Paukshtis, B.S. Balzhinimaev, A.S. Belyj. Kataliz v promyshlennosti., 6, 51-60(2013). (in Russ.). 